\title{
Organic Phosphate
}

National Cancer Institute

\section{Source}

National Cancer Institute. Organic Phosphate. NCI Thesaurus. Code C94713.

An ester of phosphoric acid, which contains phosphorus. Org anic phosphates play important roles in biochemistry and biogeochemistry or ecology. 